\title{
Examining Parameters of Surface Quality Performance of Paulownia Wood Materials Modified by Thermal Compression Technique
}

\section{Ispitivanje parametara površinske kvalitete toplinski prešanog drva paulovnije}

\author{
Original scientific paper • Izvorni znanstveni rad \\ Received-prispjelo: 11. 12. 2019. \\ Accepted-prihvaćeno: 26. 5. 2021. \\ UDK: $630 * 812.111$ \\ https://doi.org/10.5552/drvind.2021.1973
}

(C) 2021 by the author(s). Licensee Faculty of Forestry and Wood Technology, University of Zagreb. This article is an open access article distributed under the terms and conditions of the Creative Commons Attribution (CC BY) license.

\begin{abstract}
The aim of this study was to evaluate the effect of thermal compression process on some surface properties of paulownia solid wood materials. The widest surface of wood samples was mechanically compressed at high temperatures. The duration was $45 \mathrm{~min}$. Four different process combinations were created, including two temperatures $\left(150^{\circ} \mathrm{C}\right.$ and $\left.170^{\circ} \mathrm{C}\right)$ and two pressure levels $(20$ bar and $22.5 \mathrm{bar})$. The surface roughness, wettability and color properties of treated and untreated samples were compared. The roughness properties, both parallel and perpendicular to grain direction, were determined according to JIS B 0601:1994 standard. The contact angle changes of water dripped to the surface were measured according to time. For color properties, a spectrophotometer was used according to CIE $L^{*} a * b *$ system. The color changes were classifi ed according to a grading method from literature. The most remarkable results on wettability were observed. The contact angle values significantly increased with this method. Although higher temperature increased the contact angle values, higher pressures did not change the values. When the surface roughness values were generally considered, this technique could decrease the values up to $40 \%$ ratio according to the control group. Only the combination of $150{ }^{\circ} \mathrm{C}$ and 20 bar did not signifi cantly change the values. Lastly, the results of color properties showed that all treatment parameters signifi cantly affected total color change values of samples. Grading results were similar and the color change of modifi ed samples graded as the lowest color difference, except with the combination of $150{ }^{\circ} \mathrm{C}$ and 20 bar. The combination of $170^{\circ} \mathrm{C}$ and 22.5 bar (highest treatment conditions) significantly changed all color characteristics of samples, except $b^{*}$ parameter. The results of this research showed that mechanical thermal compression method could change surface properties of this fast-growing species.
\end{abstract}

Keywords: thermal compression; paulownia; wettability; contact angle; surface roughness

SAŽETAK • Cilj ovog rada bio je procijeniti učinak toplinskog prešanja na neka površinska svojstva drva paulovnije. Najveća površina uzoraka bila je prešana pri visokim temperaturama. Prešanje je trajalo 45 minuta. Primijenjene su četiri različite kombinacije uvjeta prešanja, uključujući dvije vrijednosti temperature $\left(150\right.$ i $\left.170{ }^{\circ} \mathrm{C}\right)$

\footnotetext{
${ }^{1}$ Authors are associate professor, research assistant and professor at Istanbul University - Cerrahpasa, Faculty of Forestry, Department of Forest Industrial Engineering, Istanbul, Turkey.

${ }^{2}$ Author is associate professor at Bursa Technical University, Faculty of Forestry, Department of Forest Industrial Engineering, Bursa, Turkey.
} 
i dva različita tlaka (20 i 22,5 bara). U eksperimentu su uspoređeni hrapavost površine, kvašenje i boja prešanih $i$ neprešanih uzoraka. Hrapavost je mjerena paralelno i okomito na smjer vlakanaca prema normi JIS B 0601:1994. Mjerena je i promjena kontaktnog kuta vode na površini u vremenu. Boja je određivana spektrofotometrom prema sustavu CIE $L^{*} a^{*} b^{*}$. Promjene boje klasifi cirane su primjenom klasifi kacijske metode iz literature. Najveće su promjene primijećene među vrijednostima kvašenja. Vrijednosti kontaktnog kuta značajno su se povećale prešanjem. Iako je viša temperatura utjecala na povećanje vrijednosti kontaktnog kuta, veći tlakovi nisu promijenili vrijednosti kontaktnog kuta. Ako se općenito uzmu u obzir vrijednosti hrapavosti površine, upotrijebljena bi tehnika prešanja mogla smanjiti vrijednosti hrapavosti do $40 \%$ s obzirom na kontrolne uzorke. Samo kombinacija od 150 ${ }^{\circ} \mathrm{C}$ i 20 bara nije znatnije promijenila ispitivane vrijednosti. Glede boje, rezultati su pokazali da su svi parametri prešanja bitno utjecali na ukupne vrijednosti promjene boje uzoraka. Rezultati ocjenjivanja boje bili su slični, a promjene boje prešanih uzoraka ocijenjene su kao najmanje, osim za kombinaciju $150{ }^{\circ} \mathrm{C} i 20$ bara. Pogotovo je kombinacija $170{ }^{\circ} \mathrm{C}$ i 22,5 bara (najviši parametri prešanja) značajno promijenila sve parametre boje uzoraka, osim parametra $b^{*}$. Rezultati ovog istraživanja pokazali su da bi metoda toplinskog prešanja mogla promijeniti površinska svojstva drva ove brzorastuće vrste.

Ključne riječi: toplinsko prešanje; paulovnija; kvašenje; kontaktni kut; hrapavost površine

\section{INTRODUCTION}

\section{UVOD}

Fast-growing tree species and their wood have become more preferable in recent years. However, usage area of their wood is limited due to low characteristic features. Therefore, several modification methods have been tried to increase the characteristics of these wood species. Thermal treatments as a modification method are more widely used in commercial products because the methods can be easily applied to many wood species. The methods generally change physical and mechanical properties of material while increasing some physical properties such as stability and durability. As fast-growing species already have low mechanical properties, many studies about thermal treatments focused to modify physical properties.

As a fast growing tree species, Paulownia is a deciduous species capable of achieving very high growth rates under favorable conditions. The wood of paulownia is soft, lightweight, ring-porous, straight-grained and mostly knot-free wood with a satiny luster (Kalaycioglu et al., 2004). According to Kaygin et al. (2015), density, hardness on every surface, bending strength and modulus of elasticity properties of paulownia (Paulownia elongata) were found lower than those of poplar (Populus tremula) and juniper (Juniperus excelsa). Although the characteristics of paulownia subspecies (P. elongata, P. tomentosa, P. fortunei etc.) and origins (China, Turkey) are different, they are still lower than those of many other species (Kaymakci et al., 2013).

Referring to Flynn and Holder (2001) and Clad and Pommer (1980), Akyildiz and Kol (2010) indicated that paulownia wood is used for a variety of applications such as furniture, construction, musical instruments, shipbuilding, aircraft, packing boxes, coffins, paper, plywood, cabinetmaking, and molding.

Thermal compression is a kind of modification method. The material is compressed with heated plates and kept at a constant pressure for a while in this method. It is related to viscoelastic behavior, internal and microscopic structure of wood material. Steam (Kutnar and Kamke, 2012), oil (Welzbacher et al., 2007) and other pre- or post-treatments can be applied for increasing the effect of densification. The additional treatments can give better results; however, the additional process may bring risks and costs for industrial applications.

The temperature, pressure and duration levels determine the material characteristics particularly density and surface properties such as roughness, wettability, appearance. Surface properties of wood are a determinant characteristic for use and surface treatments. It is affected by anatomic properties such as anisotropy, cell dimensions, annual ring, grain direction, and treatments such as coating and modification methods. İmirzi et al. (2014) compared the surface roughness properties of untreated and thermally compressed (with densification term) Scots pine wood. They found that the treated samples had smoother surfaces after some machining process (planing, circular sawing, sanding). Candan et al. (2013) studied thermal compression of paulownia wood boards and they found that the process could not generate an enhancement in the dimensional stability, while moisture content values decreased. However, the process caused increasing of surface density and hardness values. Otherwise, in several papers it was reported that other thermal modification methods applied to several wood species (both softwood and hardwood) changed the color of the material (González-Peña et al., 2009; Brischke et al., 2007).

The aim of this study was to examine surface quality performance of Paulownia as a fast-growing species after mechanical thermal compression. In this context, the properties of the treated samples such as surface roughness, wettability and color were investigated and compared with the untreated samples and process parameters.

\section{MATERIALS AND METHODS}

2. MATERIJALI I METODE

\subsection{Wood material and thermal compression method}

2.1. Drvni materijal i metoda toplinskog prešanja

Paulownia (Paulownia spp.) lumbers were commercially purchased from Rize, Turkey. Lumbers were 
planed and cut to obtain small and clear (defect-free) samples with dimensions of $50 \mathrm{~mm}$ by $50 \mathrm{~mm}$ by 18 $\mathrm{mm}$. Thermal compression process was mechanically performed in hot-press. The compression was applied to the widest surfaces of samples. Four treatment combinations with two-treatment temperatures $\left(150^{\circ} \mathrm{C}\right.$ and $170{ }^{\circ} \mathrm{C}$ ) and two pressure levels (20 bar and 22.5 bar) were used with 45 min duration. All experimental design is shown in Table 1. In addition, a control group with untreated samples was used to investigate the pos-

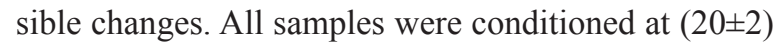
${ }^{\circ} \mathrm{C}$ and $(65 \pm 5) \%$ relative humidity $(\mathrm{RH})$ in a climate chamber until equilibrium moisture content was reached after thermal modification.

\subsection{Surface roughness measurement}

2.2. Mjerenje hrapavosti površine

The measurements were performed both parallel $(/ /)$ and perpendicular $(\perp)$ to the grain of each samples. Four roughness parameters were characterized by JIS B 0601 (1994) standard. The investigated parameters were arithmetical average roughness $(R a)$, maximum height $(R y)$ and ten-spot average roughness $(R z)$. Mitutoyo SJ-301 surface roughness tester, known as a stylus type profile-meter, was used for the tests (Anon., 2002). The measurements were performed with $0.5 \mu \mathrm{m}$ accuracy. The speed of stylus type pin was $10 \mathrm{~mm} / \mathrm{min}$ and $\lambda \mathrm{c}$ value was $12.5 \mathrm{~mm}$.

\subsection{Wettability measurement}

\subsection{Mjerenje kvašenja}

Contact angle $(C A)$ values were obtained to determine the wettability characteristics of the samples. They were determined using KSV Cam-101 Scientific Instru-

Table 1 Experimental design of thermal compression process Tablica 1. Plan eksperimenta toplinskog prešanja

\begin{tabular}{|c|c|c|c|}
\hline \multirow[b]{2}{*}{$\begin{array}{l}\text { Panel } \\
\text { group } \\
\text { Grupa } \\
\text { ploče }\end{array}$} & \multicolumn{3}{|c|}{ Treatment conditions / Parametri prě̌anja } \\
\hline & $\begin{array}{c}\text { Temperature, } \\
{ }^{\circ} \mathbf{C} \\
\text { Temperatura, } \\
{ }^{\circ} \mathrm{C}\end{array}$ & $\begin{array}{l}\text { Pressure, bar } \\
\text { Tlak, bar }\end{array}$ & $\begin{array}{l}\text { Duration, } \\
\text { min } \\
\text { Trajanje, min }\end{array}$ \\
\hline Control & - & - & - \\
\hline A & 150 & 20.0 & 45 \\
\hline B & 150 & 22.5 & 45 \\
\hline $\mathrm{C}$ & 170 & 20.0 & 45 \\
\hline D & 170 & 22.5 & 45 \\
\hline
\end{tabular}

ment (Helsinki, Finland) device. $5 \mu \mathrm{L}$ droplet of distilled water was used as the liquid. After the water droplet was dripped on the pressured surface, the camera of the device captured 30 images at 1 -second intervals. $C A$ values from the images were measured with image processing software. The mean of two-contact angle values (left and right) were used to analyze each image.

\subsection{Determination of color characteristics \\ 2.4. Određivanje svojstava boje}

The color measurements were carried out using a Minolta CM-2600d spectrophotometer (Konica Minolta, Japan) equipped with an integrating sphere according to the $C I E L^{*} a^{*} b^{*}$ system. The system consists of three parameters: $L^{*}, a^{*}$ and $b^{*}$. The $L^{*}$ axis represents the lightness and varies from 0 (black) to 100 (white). The symbol $+a^{*}$ is for red, $-a^{*}$ for green, $+b^{*}$ for yellow and $-b^{*}$ for blue. Moreover, brightness (R457 nm) was determined according to ISO 2470 standard), while whiteness and yellowness were determined according to ASTM E313 standard. Total color change $\Delta E^{*}$ was calculated using the $L^{*}, a^{*}$ and $b^{*}$ data of each sample according to the equation given below (Eq. 1) (In equation, each " $\Delta$ " indicates the difference of each parameter). Additionally, the magnitude of $\Delta E$ results were classified according to the grading rules suggested by Cividini et al. (2007) (Table 2).

$$
\Delta E^{*}=\left[\left(\Delta L^{*}\right)^{2}+\left(\Delta a^{*}\right)^{2}+\left(\Delta b^{*}\right)^{2}\right]^{1 / 2}
$$

For comparison of all groups, multiple comparisons were first subjected to an analysis of variance (ANOVA), and significant differences between average values of control and treated samples were determined using Duncan's multiple range test with SPSS Software. $p$-values of 0.05 were considered to determine significance level.

\section{RESULTS AND DISCUSSION 3. REZULTATI I RASPRAVA}

Control and treated sample groups were compared and homogeneity groups were determined for each test according to the Duncan's multiply range test. The surface roughness results are shown in Table 3.

As seen in Table 3, some statistically significant differences $(p<0.05)$ were found to exist as determined by Duncan's multiple-comparison tests. When

Table 2 Total color change $(\Delta E)$ grading rules (Cividini et al., 2007)

Tablica 2. Pravila ocjenjivanja ukupne promjene boje $(\Delta E)$ (Cividini et al., 2007.)

\begin{tabular}{|c|c|c|}
\hline $\begin{array}{l}\Delta \boldsymbol{E} \text { value } \\
\Delta E \text { vrijednost }\end{array}$ & Observation / Zapažanje & $\begin{array}{c}\text { Change level* } \\
\text { Stupanj promjene* }\end{array}$ \\
\hline $0.2>\Delta E$ & Not visible difference / nema vidljivih razlika & 0 \\
\hline $0.2<\Delta E<2$ & Small difference / male razlike & 1 \\
\hline $2<\Delta E<3$ & $\begin{array}{l}\text { Color difference visible with high quality screen } \\
\text { razlika boje vidljiva uz pomoć ekrana visoke kvalitete }\end{array}$ & 2 \\
\hline $3<\Delta E<6$ & $\begin{array}{l}\text { Color difference visible with medium quality screen } \\
\text { razlika boje vidljiva putem ekrana srednje kvalitete }\end{array}$ & 3 \\
\hline $6<\Delta E<12$ & High color difference / izrazita razlika u boji & 4 \\
\hline$\Delta E>12$ & Different colors / različite boje & 5 \\
\hline
\end{tabular}

*The change levels were determined for this paper. / Stupnjevi promjene određeni za ovaj rad. 
Table 3 The effect of thermal compression with different durations on surface roughness of paulownia wood* Tablica 3. Utjecaj toplinskog prešanja i njegova trajanja na hrapavost površine drva paulovnije*

\begin{tabular}{|c|c|c|c|c|c|c|c|}
\hline \multirow{2}{*}{$\begin{array}{c}\text { Temperature, }{ }^{\circ} \mathbf{C} \\
\text { Temperatura, },{ }^{\circ} \mathrm{C}\end{array}$} & \multirow{2}{*}{$\begin{array}{l}\text { Pressure, bar } \\
\text { Tlak, bar }\end{array}$} & \multicolumn{2}{|c|}{$R a(\mu \mathrm{m})$} & \multicolumn{2}{|c|}{$R y(\mu \mathrm{m})$} & \multicolumn{2}{|c|}{$R z(\mu \mathrm{m})$} \\
\hline & & $1 /$ & $\perp$ & // & $\perp$ & // & $\perp$ \\
\hline \multicolumn{2}{|c|}{ Control / Kontrolni uzorci } & $\begin{array}{l}3.95^{\mathrm{b}} \\
(0.90)\end{array}$ & $5.23^{\mathrm{bc}}(1.15)$ & $\begin{array}{l}21.78^{\mathrm{ab}} \\
(3.86)\end{array}$ & $\begin{array}{l}37.39^{\mathrm{b}} \\
(5.78)\end{array}$ & $\begin{array}{l}14.34^{\mathrm{ab}} \\
(2.91)\end{array}$ & $\begin{array}{l}26.21^{\mathrm{cd}} \\
(3.44)\end{array}$ \\
\hline 150 & 20.0 & $4.00^{\mathrm{b}}(1.00)$ & $6.10^{c}(2.09)$ & $\begin{array}{l}24.76^{\mathrm{b}} \\
(6.00) \\
\end{array}$ & $\begin{array}{l}40.82^{b} \\
(10.43) \\
\end{array}$ & $\begin{array}{l}15.96^{\mathrm{b}} \\
(4.16)\end{array}$ & $\begin{array}{l}28.28^{\mathrm{d}} \\
(6.42)\end{array}$ \\
\hline 150 & 22.5 & $2.71^{\mathrm{a}}(0.49)$ & $4.07^{\mathrm{ab}}(0.77)$ & $\begin{array}{l}17.84^{\mathrm{a}} \\
(3.04)\end{array}$ & $\begin{array}{l}30.54^{\mathrm{a}} \\
(5.58)\end{array}$ & $\begin{array}{l}11.40^{\mathrm{a}} \\
(1.84)\end{array}$ & $\begin{array}{l}22.16^{\text {bc }} \\
(3.21)\end{array}$ \\
\hline 170 & 20.0 & $3.32^{\mathrm{ab}}(0.91)$ & $3.81^{\mathrm{a}}(1.38)$ & $\begin{array}{l}19.88^{\mathrm{a}} \\
(4.68) \\
\end{array}$ & $\begin{array}{l}27.58^{\mathrm{a}} \\
(7.85)\end{array}$ & $\begin{array}{l}12.63^{\mathrm{a}} \\
(3.27)\end{array}$ & $\begin{array}{r}19.75^{\mathrm{ab}} \\
(5.50)\end{array}$ \\
\hline 170 & 22.5 & $\begin{array}{l}2.63^{\mathrm{a}} \\
(0.98)\end{array}$ & $3.09^{\mathrm{a}}(0.70)$ & $\begin{array}{l}18.49^{\mathrm{a}} \\
(4.69)\end{array}$ & $\begin{array}{l}25.42^{\mathrm{a}} \\
(5.69)\end{array}$ & $\begin{array}{l}11.53^{\mathrm{a}} \\
(3.70)\end{array}$ & $\begin{array}{r}22.16^{\text {bc }} \\
(4.16) \\
\end{array}$ \\
\hline
\end{tabular}

* Mean (standard deviation) and the same letter on numbers in the same column show that there is no difference in group homogeneity for each parameter $(p<0.05)$. / Srednja vrijednost (standardna devijacija) $i$ isto slovo uz brojeve u istom retku pokazuju da nema razlike $u$ homogenosti grupa za svaki parametar $(p<0,05)$.

all values generally considered, surface roughness values decreased up to $40 \%$. Only combination of $150^{\circ} \mathrm{C}$ and 20 bar did not significantly change the values. When the values were considered in detail, the values of Control and $150^{\circ} \mathrm{C}-20$ bar groups were higher than other treatment groups for all directions. When the pressure effect was investigated (at the same temperatures), there was significant change at the temperature of $150^{\circ} \mathrm{C}$, while there was no significant change at 170 ${ }^{\circ} \mathrm{C}$. When the temperature effect was investigated (at the same pressures), there was significant change with temperature increment at 20 bar pressure, while there was no significant change at 22.5 bar. In addition, similar changes were obtained in both directions.

Dogu et al. (2017) similarly applied thermal compression method to paulownia wood with only 20 bar pressure at the same temperatures. They observed that slightly more cellular damage occurred in the treated samples and found that distribution of deformation was not uniform in the growth rings of the treated samples. Their comment might explain the similarity of roughness values between Control and $150{ }^{\circ} \mathrm{C} 20$ bar groups. Although there are more differences between Control and $170{ }^{\circ} \mathrm{C} 20$ bar roughness values, they were only limited to perpendicular direction. However, the pressure levels and/or duration can be increased to affect the material properties and to obtain smoother surface, because the material thickness can decrease by half, as stated in some studies. Although useful results were obtained with stylus-based technique, the measurements were realized with different steps through a line with perpendicular and parallel directions to grain. Areal measurement might be required for wider evaluation.

The contact angle $(C A)$ results of the samples are presented in Table 4.

As seen in Table 4, statistically significant differences $(p<0.05)$ were found to exist as determined by Duncan's multiple-comparison tests. The contact angle $(C A)$ values for all treated samples increased with increasing thermal compression treatment, especially with increment in temperature according to control (untreated) samples. It was found that the $C A$ values were in-
Table 4 The effect of thermal treatment with different durations on wettability of paulownia wood*

Tablica 4. Utjecaj toplinskog prešanja i njegova trajanja na kvašenje drva paulovnije*

\begin{tabular}{|c|c|c|}
\hline $\begin{array}{c}\text { Temperature, }{ }^{\circ} \mathbf{C} \\
\text { Temperatura, }{ }^{\circ} \mathrm{C}\end{array}$ & $\begin{array}{c}\text { Pressure, bar } \\
\text { Tlak, bar }\end{array}$ & $\begin{array}{c}\text { Contact angle, }^{\circ} \\
\text { Kontaktni kut, }^{\circ}\end{array}$ \\
\hline \multicolumn{2}{|c|}{ Control / Kontrola } & $30.63^{\mathrm{a}}(11.79)$ \\
\hline 150 & 20.0 & $59.98^{\mathrm{b}}(9.28)$ \\
\hline 150 & 22.5 & $53.80^{\mathrm{b}}(14.21)$ \\
\hline 170 & 20.0 & $82.59^{\mathrm{c}}(16.16)$ \\
\hline 170 & 22.5 & $84.78^{\mathrm{c}}(12.05)$ \\
\hline
\end{tabular}

* Mean (standard deviation) and the same letter on numbers in the same column show that there is no difference in group homogeneity for each parameter $(p<0.05)$. / Srednja vrijednost (standardna devijacija) $i$ isto slovo uz brojeve u istom retku pokazuju da nema razlike $u$ homogenosti grupa za svaki parametar $(p<0,05)$.

creased when the treatment temperature increased. However, significant differences were not observed with changing pressure for both temperatures. It can be said that thermal compression gained the hydrophobic character to the wood surface. At $170^{\circ} \mathrm{C}$, the $C A$ values reached nearly $90^{\circ}$, which may show enough hydrophobicity for a wood material. Hakkou (2005) indicated that investigation of the effect of temperature on wettability showed that it changes suddenly for temperatures between $130{ }^{\circ} \mathrm{C}$ and $160{ }^{\circ} \mathrm{C}$, indicating that higher temperatures, generally used for heat treatment, are not necessary to modify wood hydrophilic properties.

Examining other studies, Mirzaei et al. (2012) found that, by the rise of the treatment temperature, the contact angle values of paulownia wood samples were increased to $100{ }^{\circ} \mathrm{C}$ and $150^{\circ} \mathrm{C}$ with a 30 -minute hydrothermal treatment. Candan et al. (2011) found similar decrease in wettability of poplar wood under similar treatment conditions, namely $170^{\circ} \mathrm{C}$ and $190^{\circ} \mathrm{C}$ for 60 minutes without pressure. The obtained contact angle values are suitable for many surface treatments. However, Laskowska and Sobczak (2018) increased pressure 20 times more with shorter durations. They found similar decrease in wettability of oak wood under similar treatment conditions, namely $150^{\circ} \mathrm{C}$ and 450 bar for 8 min treatment. 
........ Candan, Gonultas, Gorgun, Unsal: Examining Parameters of Surface Quality ...

Table 5 Color change of each group*

Tablica 5. Promjena boje svake grupe*

\begin{tabular}{|c|c|c|c|c|c|c|c|}
\hline $\begin{array}{c}\text { Temperature, }{ }^{\circ} \mathrm{C} \\
\text { Temperatura, }{ }^{\circ} \mathrm{C}\end{array}$ & $\begin{array}{c}\text { Pressure, bar } \\
\text { Tlak, bar }\end{array}$ & $\boldsymbol{L}^{*}$ & $\boldsymbol{a}^{*}$ & $\boldsymbol{b}^{*}$ & $\begin{array}{c}\text { Brightness } \\
\text { Svjetlina }\end{array}$ & $\begin{array}{c}\text { Whiteness } \\
\text { Bjelina }\end{array}$ & $\begin{array}{c}\text { Yellowness } \\
\text { Źućenje }\end{array}$ \\
\hline \multicolumn{2}{|c|}{ Control / Kontrolni uzorci } & $77.12(0.69)^{\mathrm{c}}$ & $5.07(0.74)^{\mathrm{a}}$ & $15.37(0.83)^{\mathrm{a}}$ & $\begin{array}{c}39.07 \\
(1.41)^{\mathrm{c}}\end{array}$ & $\begin{array}{c}51.74 \\
(1.16)^{\mathrm{c}}\end{array}$ & $\begin{array}{c}36.89 \\
(2.22)^{\mathrm{a}}\end{array}$ \\
\hline \multirow{3}{*}{150} & 20.0 & $65.10(6.94)^{\mathrm{b}}$ & $6.94(1.54)^{\mathrm{b}}$ & $23.75(1.52)^{\mathrm{b}}$ & $\begin{array}{c}20.70 \\
(6.27)^{\mathrm{b}}\end{array}$ & $\begin{array}{c}34.78 \\
(8.24)^{\mathrm{b}}\end{array}$ & $\begin{array}{c}60.73 \\
(8.20)^{\mathrm{b}}\end{array}$ \\
\cline { 2 - 9 } & 22.5 & $66.38(2.63)^{\mathrm{b}}$ & $6.72(0.88)^{\mathrm{b}}$ & $22.87(1.51)^{\mathrm{b}}$ & $\begin{array}{c}21.86 \\
(3.27)^{\mathrm{b}}\end{array}$ & $\begin{array}{c}35.91 \\
(3.47)^{\mathrm{b}}\end{array}$ & $\begin{array}{c}57.73 \\
(5.02)^{\mathrm{b}}\end{array}$ \\
\hline \multirow{3}{*}{170} & 20.0 & $61.08(7.11)^{\mathrm{b}}$ & $7.53(1.18)^{\mathrm{b}}$ & $22.84(2.50)^{\mathrm{b}}$ & $\begin{array}{c}17.55 \\
(5.43)^{\mathrm{b}}\end{array}$ & $\begin{array}{c}29.97 \\
(8.75)^{\mathrm{b}}\end{array}$ & $\begin{array}{c}62.01 \\
(5.32)^{\mathrm{b}}\end{array}$ \\
\cline { 2 - 9 } & 22.5 & $52.16(2.86)^{\mathrm{a}}$ & $9.32(0.89)^{\mathrm{c}}$ & $23.71(1.84)^{\mathrm{b}}$ & $\begin{array}{c}10.67 \\
(1.48)^{\mathrm{a}}\end{array}$ & $\begin{array}{c}20.39 \\
(2.60)^{\mathrm{a}}\end{array}$ & $\begin{array}{c}72.74 \\
(4.54)^{\mathrm{c}}\end{array}$ \\
\hline
\end{tabular}

* Mean (standard deviation) and the same letter on numbers in the same column show that there is no difference in group homogeneity for each parameter $(p<0.05)$. / Srednja vrijednost (standardna devijacija) $i$ isto slovo uz brojeve u istom retku pokazuju da nema razlike u homogenosti grupa za svaki parametar $(p<0,05)$.

Table 6 Total color change $(\Delta E)$ according to each treatment parameter*

Tablica 6. Ukupna promjena boje $(\Delta E)$ za pojedini parametar prešanja

\begin{tabular}{|l|c|c|c|}
\hline \multicolumn{2}{|c|}{ Variables $/$ Varijable } & $\begin{array}{c}\Delta E \text { values } \\
\Delta E \text { vrijednosti }\end{array}$ & $\begin{array}{c}\text { Change level } \\
\text { Stupanj promjene }\end{array}$ \\
\hline Control & $20.0 \mathrm{bar}-150^{\circ} \mathrm{C}$ & $15.12(7.22)^{\mathrm{cd}}$ & 5 \\
\hline Control & $22.5 \mathrm{bar}-150^{\circ} \mathrm{C}$ & $13.30(3.26)^{\mathrm{bcd}}$ & 5 \\
\hline Control & $20.0 \mathrm{bar}-170^{\circ} \mathrm{C}$ & $18.70(5.40)^{\mathrm{d}}$ & 5 \\
\hline Control & $22.5 \mathrm{bar}-170^{\circ} \mathrm{C}$ & $26.77(2.50)^{\mathrm{e}}$ & 5 \\
\hline $20.0 \mathrm{bar}-150^{\circ} \mathrm{C}$ & $22.5 \mathrm{bar}-150^{\circ} \mathrm{C}$ & $6.49(4.01)^{\mathrm{a}}$ & 3 \\
\hline $20.0 \mathrm{bar}-170^{\circ} \mathrm{C}$ & $22.5 \mathrm{bar}-170^{\circ} \mathrm{C}$ & $9.40(7.74)^{\mathrm{abc}}$ & 4 \\
\hline $20.0 \mathrm{bar}-150^{\circ} \mathrm{C}$ & $20.0 \mathrm{bar}-170^{\circ} \mathrm{C}$ & $7.28(4.16)^{\mathrm{ab}}$ & 4 \\
\hline $22.5 \mathrm{bar}-150^{\circ} \mathrm{C}$ & $22.5 \mathrm{bar}-170^{\circ} \mathrm{C}$ & $14.69(3.79)^{\mathrm{cd}}$ & 5 \\
\hline
\end{tabular}

* Mean (standard deviation) and the same letter on numbers in the same column show that there is no difference in group homogeneity for each parameter $(p<0.05)$. / Srednja vrijednost (standardna devijacija) i isto slovo uz brojeve u istom retku pokazuju da nema razlike u homogenosti grupa za svaki parametar $(p<0,05)$.

The color change results of samples are presented in Table 5 and total color changes of each treatment parameter related to control group and to each other are presented in Table 6.

As seen in tables, thermal compression process changed the color tones and brightness of samples when the results were compared with control (untreated) samples. Results showed that $170{ }^{\circ} \mathrm{C}$ and $22.5 \mathrm{bar}$ process conditions significantly changed all color characteristics of samples, while only $b^{*}$ parameter was similar with other process conditions. As seen in Table 6 , all treatment parameters significantly affected total color change values of samples. The changes were more pronounced at the temperature of $170^{\circ} \mathrm{C}$. Otherwise, the pressure increment was only significant at the temperature of $170{ }^{\circ} \mathrm{C}$, when the total color change was compared with control samples.

The color values of the samples changed significantly when the temperature changed; additionally, the change was higher at the temperature of $170^{\circ} \mathrm{C}$. Kaygin et al. (2009) found similar changes of $L^{*}, a^{*}$ and $b^{*}$ on paulownia samples although they carried out conventional heat treatment at $160{ }^{\circ} \mathrm{C}, 180{ }^{\circ} \mathrm{C}$ and $200^{\circ} \mathrm{C}$ without pressure.

Atik et al. (2013) and Akkus and Budakci (2015) similarly found that the color change increased with temperature increment, although they used different species. Their results showed that the higher tempera- ture was applied to the material, the greater decrease was observed in the lightness value, as in this study. The color change, especially getting dark, ( $L^{*}$ value decrement) can extend the use of this fast-growing wood species, paulownia, as it can be considered exclusive in the market.

\section{CONCLUSIONS}

4. ZAKLJUČAK

In this study, one of the thermal modification techniques, mechanical thermal compression, was used for trying to change some surface characteristics of a fast-growing wood species - paulownia. Results showed that some significant changes of surface roughness, wettability, color properties were observed with some temperature and pressure combinations.

The observed changes showed that the properties of a fast-growing tree species, paulownia, can change. If these properties may be determined as reasonable for some uses, the market share of paulownia can increase. Kaymakci et al. (2013) pointed out that this situation can play a major role for countries that have poor wood resources for lumber production. Future studies should focus on changing modification possibilities by observing together anatomical structure and mechanical properties, because the applied pressure and temperature levels may be critical for the above properties. 


\section{Acknowledgements - Zahvala}

The authors thank Istanbul University-Cerrahpasa Research Fund for its financial support in this study. Otherwise, this article is an extension and continuation of the study presented at the ORENKO 2018-International Forest Products Congress.

\section{REFERENCES}

5. LITERATURA

1. Akkus, M.; Budakci, M., 2015: Effects of color change of heat-treated some wood materials. In: Proceedings of $27^{\text {th }}$ International Conference Research for Furniture Industry (206-215), 17-18 September 2015, Gazi University, Ankara, TURKEY.

2. Akyildiz, M. H.; Kol Sahin, H., 2010: Some technological properties and uses of paulownia (Paulownia tomentosa Steud.) wood. Journal of Environmental Biology, 31: 351-355.

3. Atik, C.; Candan, Z.; Unsal, O., 2013: Colour characteristics of pine wood affected by thermal compressing. Ciência Florestal, 23 (2): 475-479. http://dx.doi.org/10.5902/198050989291.

4. Brischke, C.; Welzbacher, C. R.; Brandt, K.; Rapp, A. O., 2007: Quality control of thermally modified timber: Interrelationship between heat treatment intensities and CIE $L * a * b *$ color data on homogenized wood samples. Holzforschung, 61 (1): 19-22. https://doi.org/10.1515/HF.2007.004.

5. Candan, Z.; Büyüksarı, U.; Korkut, S.; Unsal, O.; Çakıcıer, N., 2012: Wettability and surface roughness of thermally modified plywood panels. Industrial Crops and Products, 36 (1): 434-436.

https:// doi:10.1016/j.indcrop.2011.10.010.

6. Candan, Z.; Korkut, S.; Unsal, O., 2013: Effect of thermal modification by hot pressing on performance properties of paulownia wood boards. Industrial Crops and Products, 45: 461-464. https://doi.org/10.1016/j.indcrop.2012.12.024.

7. Cividini, R.; Travan, L.; Allegretti, O., 2007: White beech: A tricky problem in drying process. In: Proceedings of $7^{\text {th }}$ ISCHP (International Scientific Conference on Hardwood Processing), 24-26 September 2007, Quebec City, Canada.

8. Clad, W.; Pommer, E., 1980: Manufacture of particleboard from kiri (Paulownia tomentosa, Fam. Scrouphulariaceae). Holz als Roh- und Werkstoff, 38: 385-391. https://doi.org/10.1007/BF02607484.

9. Dogu, D.; Tuncer, F. D.; Bakir, D.; Candan, Z., 2017: Characterizing microscopic changes of paulownia wood under thermal compression. BioResources, 12 (3): 52795295. https://doi.org/10.15376/biores.12.3.5279-5295.

10. Flynn, H.; Holder, C., 2001: Useful wood of the world. Forest Products Society, Madison, WI.

11. González-Peña, M. M.; Hale, M. D., 2009: Colour in thermally modified wood of beech, Norway spruce and Scots pine. Part 1: Colour evolution and colour changes. Holzforschung, 63 (4): 385-393. https://doi.org/10.1515/hf.2009.078.

12. Hakkou, M.; Pétrissans, M.; Zoulalian, A.; Gérardin, P., 2005: Investigation of wood wettability changes during heat treatment on the basis of chemical analysis. Polymer degradation and stability, 89 (1): 1-5. https://doi.org/10.1016/j.polymdegradstab.2004.10.017.

13. İmirzi, H. Ö.; Ülker, O.; Burdurlu, E., 2013: Effect of densification temperature and some surfacing techniques on the surface roughness of densified Scots pine (Pinus sylvestris L.). BioResources, 9 (1): 191-209. https://doi.org/10.15376/biores.9.1.191-209.

14. Kalaycioglu, H.; Deniz, I.; Hiziroglu, S., 2005: Some of the properties of particleboard made from paulownia. Journal of Wood Science, 51 (4): 410-414. https://doi.org/10.1007/s10086-004-0665-8.

15. Kaygin, B.; Gunduz, G.; Aydemir, D., 2009: Some physical properties of heat-treated Paulownia (Paulownia elongata) wood. Drying Technology, 27 (1): 89-93. http://dx.doi.org/10.1080/07373930802565921.

16. Kaygin, B.; Kaplan, D.; Aydemir, D., 2015: Paulownia tree as an alternative raw material for pencil manufacturing. BioResources, 10 (2): 3426-3433. https://doi.org/10.15376/biores.10.2.3426-3433.

17. Kaymakci, A.; Bektaş, İ.; Bal, B. C., 2013: Some mechanical properties of paulownia (Paulownia elongata) wood. In: Proceedings of International Caucasian Forestry Symposium, 24-26 October 2013, Artvin, Turkey, pp. 917-919.

18. Kutnar, A., Kamke, F. A., 2012: Compression of wood under saturated steam, superheated steam, and transient conditions at $150{ }^{\circ} \mathrm{C}, 160^{\circ} \mathrm{C}$, and $170{ }^{\circ} \mathrm{C}$. Wood Science and Technology, 46: 73-88. https://doi.org/10.1007/s00226-010-0380-0.

19. Laskowska, A.; Sobczak, J. W., 2018: Surface chemical composition and roughness as factors affecting the wettability of thermo-mechanically modified oak (Quercus robur L.). Holzforschung, 72 (11): 993-1000. https://doi.org/10.1515/hf-2018-0022.

20. Mirzaei, G. H.; Mohebby, B.; Tabarsa, T., 2012: Collapsibility and wettability of hydrothermally treated wood. Iranian Journal of Wood and Paper Industries, 3 (1): 1-11.

21. Welzbacher, C. R.; Wehsener, J.; Rapp, A. O.; Haller, P., 2008: Thermo-mechanical densification combined with thermal modification of Norway spruce (Picea abies Karst) in industrial scale - Dimensional stability and durability aspects. Holz als Roh- und Werkstoff, 66: 39-49. https://doi.org/10.1007/s00107-007-0198-0.

22. ***Anonymous, 2002: Mitutoyo surface roughness tester, Mitutoyo Surftest SJ-301, Product no. 99MBB035A 1. Series No. 178, Mitutoyo Corporation, 20-1, Sakado 1-chome, Takatsu-ku, Kawasaki, Kanagawa 213-0012, Japan.

23. ***ASTM E313-15e1, 2015: Standard Practice for Calculating Yellowness and Whiteness Indices from Instrumentally Measured Color Coordinates, ASTM International, West Conshohocken, PA.

24. ***ISO 2470-2, 2008: Paper, board and pulps - Measurement of diffuse blue reflectance factor, Part 2: Outdoor daylight conditions (D65 brightness). International Organization for Standardization.

25. ***JIS B 0601, 1994: Geometrical Product Specifications (Gps) - Surface Texture: Profile Method - Terms, Definitions and Surface Texture Parameters. Japanese Standards Association (JSA), Japan.

\section{Corresponding address:}

\section{ZEKI CANDAN}

Istanbul University - Cerrahpasa

Faculty of Forestry

Department of Forest Industrial Engineering

Sariyer, 34473, Istanbul, TURKEY

e-mail: zekic@istanbul.edu.tr 